\title{
Percent Predicted Forced Expiratory Volume in 1 Second
}

National Cancer Institute

\section{Source}

National Cancer Institute. Percent Predicted Forced Expiratory Volume in 1 Second. NCI

Thesaurus. Code C112376.

Forced expiratory volume in one second as a proportion of the predicted normal value. (CDISC) 